\title{
Collective Identities in Migration. Biographical Perspectives on Ambivalences and Paradoxes
}

\author{
Roswitha Breckner \\ Department of Sociology, Faculty of Social Sciences, University of Vienna, Austria \\ *Corresponding Author: Roswitha.breckner@univie.ac.at
}

Copyright (C) 2014 Horizon Research Publishing All rights reserved.

\begin{abstract}
Notwithstanding the deconstruction of essentialist concepts of national or ethnic identity also with respect to the growing movements between nation states and developing transnational spheres [1-4], to construct collective belongings with references to imagined communities [5] based in nation, culture or ethnicity still seems to be a relevant social practice. At the same time, we can observe increasing ambivalences and even paradoxes inherent in these practices. They show when looking at biographical processes in which collective belongings concretely take shape. Based on empirical research on East-West European migration during the Cold War [6], I would like to demonstrate in this article how different biographical experiences interconnect when national, cultural, ethnic or other collective identities emerge, and also when they drop to the background in processes of undoing a collective identity.
\end{abstract}

Keywords Collective Identities; We-Relations; Biographical Research; Migration Research; Division of Europe During The Cold War; Romania

\section{Introduction}

In social sciences, the significance of collective identities in migration processes normally is discussed by drawing on quantitative data from investigation in which the categories of belonging like 'national' or 'ethnic' are fixed in the questionnaires. These approaches might show self-definitions of the investigated groups and population at a certain point of time. However, from this research we get almost no understanding how the self-positioning has developed in which social contexts by dealing with which specific challenges in the life worlds of those concerned. In this article I would like to present a research perspective which takes the concrete biographical and societal circumstances of developing and changing collective belongings in migration processes into account.

Let me start with a quote from the biographical narrative interview with Stefan Georgescu:
"In the twentieth century it is taken for granted that artists are emigrants. (...)It was not easy for me as a young man to be in such different countries, especially in America. Then I remembered all these great names and said to myself, as an artist you are at home everywhere and that helped me somehow. And then later, when I was over thirty, I felt like a citizen of the world. I said I am at home in any country (...). But then I realized finally that someone who is born in France or in Germany or elsewhere can say-regardless of where he lives-I am German. But what will you say you are? I no longer had the self-determination to say, I am Romanian, that doesn't work [draws in air]. And then I said, maybe a part of me is as if handicapped, so that I don't have this ethnic-national function [sniffs], and then I said, you must be happy with being what you are, but now I am ambivalent again. Now I think it was a bad joke of nature that I was born in Romania (...). I said to my mother, "You are Armenian; there are Armenians all over the world, why did you give birth to me in Romania? Couldn't you have stayed in Odessa or where you were born?" And now I think, at this juncture, I wish I had not been born in Romania, I really do." (Stefan Georgescu)

In this evaluating coda[7] of a longer story about migration experiences within a biographical interview, Stefan Georgescu - as I call the interviewee - summarizes in a condensed way his experiences with his ethnic and national identities. He places them in the context of the twentieth century; in a professional milieu of emigrated artists; and connects them with different life phases ('young man in America'; 'over thirty'). The self-determination of being a cosmopolite ('citizen of the world') seemed to be a solution for a while, but was contested when Stefan realized that it does not equate an ethnic or national identity. Not being able to say 'what you are' to him even felt like a 'handicap'. But also to refer to the national identity connected to his place of birth is considered as 'a bad joke of nature'. Being born in Romania from an Armenian family and after having lived in the US, in France and Germany for longer periods of his life, Stefan presents in this part of the interview an ongoing struggle with his attachments to different national and ethnic collectivities, ending up in ambivalence towards his links to Romania as his place of birth. Even though he attempted to 
get rid of this seemingly imposed belonging, his stories and reflections throughout the interview show how strongly he is occupied with it at the time the interview took place. In a more general sense this passage also shows that for Stefan his national and ethnic identities are nothing given, continuous or stable, even though he felt to be bound to them "naturally".

Leaving the interpretation of the quote at this point, it would just confirm what we already know from critical discussions on concepts of identity [8-10]. Identities are shaped in processes by acquiring, living in and moving through different social contexts and positions in families, generations, milieus, life spheres, institutions, societies, and not least collectivities constructed as national or ethnic ones. The actual placing, be it by others or by oneself, is part of the processes in which social positions are created, stabilized, changed and transformed. Sociological concepts of biography [11-15] build on this perspective on identity [16], and try to avoid static or even essentialist imaginations still connected with the term identity [17]. Biographical research aims at grasping the complex interplay between different social positions, life spheres and socio-biographical processes from the life-perspective of actors who are concretely involved in timely as well as locally more or less far reaching and changing social contexts [18-25] Biographical approaches are widely used also in migration research [26-29].

Looking at the initial quote from such a biographical perspective, it generates more questions than answers. Under which biographical as well as societal circumstances the national and ethnic identities became relevant in the case of Stefan Georgescu? How the national and ethnic relations were embedded in the complexity of his developing experiences and life contexts? How did they emerge, transform and drop to the background?

Following the traces of intertwined experiential contexts which have turned out to be highly relevant in the case of Stefan Georgescu, the aim of this article is to conceptually show what one can gain looking at collective identities from a biographical perspective. Even though Stefan Georgescu is a case example for conceptual arguments rather than for presenting an empirical result, the empirical contexts of his biography are crucial to understand the processes, and mainly the ambivalences and even paradoxes, in which his collective identities developed. Especially the polarization between the East and the West of Europe during the Cold War and its aftermath in the restructuring processes after 1989 turned out to be the field in which the collective identities of Stefan Georgescu became relevant in different ways at different times in different life spheres.

Before following the life history and story of Stefan Georgescu in detail, I first would like to elaborate on the specific viewpoints possible in migration research if a sociological concept of biography is consequently used (2.). In the third part of this article I introduce the broader context of my research on East-West-European migration during the Cold War in which the case study of Stefan Georgescu is embedded (3.). The latter is presented by focusing on the concrete biographical and societal contexts which have become relevant in Stefan's dealing with collective identities and on how they are intertwined (4.). Concluding, I argue that ambivalences and paradoxes in building collective identities arising on societal levels have to be dealt with biographically. Especially in migratory situations biographers become aware of ambivalences in building we-relations and have to find ways to deal with attachments to and rejections of ascribed as well as experienced collectivities in changing life contexts and periods with changing relevance (5.).

\section{The Biographical Perspective as Conceptual Approach in Migration Research}

The classical study of Thomas \& Znaniecki on "The Polish Peasant in Europe and America" [30] has already shown the importance of biographical dimensions in transforming societies by migration processes, in that case from Poland to the US during the turn from the 19th to 20th century. The biographical perspective was introduced to understand how social change in general, and specifically the emergence and change of institutions and social structures was brought about by actors who had to reconstruct their lives. The approach of Thomas and Znaniecki has been taken up again in the 1970ies as point of reference for developing qualitative methods [31] and was methodologically and methodically refined in the course of critical discussions.

From the perspective of current sociological concepts of biography we can assume that biographies are constituted by experiences lived through and the formation of stories about 'how one has become who we are' $[32,33]$.

The narration itself is creating the biography as interconnection between experiences which are thematically and timely related to each other from a present perspective with an underlying, mostly implicit meaning. In turn, the present overall biographical perspective [7] develops by living through and dealing with a huge variety of situations and social contexts. The sequence of relevant biographical events and corresponding experiences shows what a person underwent in the course of her life. In turn, by reconstructing the implicit structuring principles of how a biography is narrated we can grasp the overall perspective with which a person is retrospectively referring to her life. It is the interrelation between the life history and the life story that finally forms a biography [34].

To look at collective identities from this perspective means to grasp how they are done [35] in directly talking about and indirectly referring to experiences which locate us in a social field organized by national or ethnic boundaries [36]. Biographical practices of doing a national or ethnic identity can not only vary widely, but also can change profoundly in a lifetime, in generational, milieu and 
many other contexts. Therefore, a collective identity is nothing given but something to become, even though it seems like we have it already by being part of an already structured social sphere, e.g. by being born within a territory, ethnic community or by other ascriptive criteria placing us right from the beginning of our life. Especially in migration processes the doing of national or ethnic identities becomes apparent since they no longer can be taken for granted, and eventually are compared to other principles of constructing collective identities in other societal contexts. Arising questions of belonging in turn lead to biographical reflexion on 'how one has become what one is'. This can challenge categorisation along ethnic and national boundaries in general, and especially when it excludes the experiential complexities of becoming by moving through different and even contradictorily organized social worlds.

The paradox of being ascribed to a given and to some extent also continuous national and/or ethnic identity, and to develop attachments to changing collective entities in a life course placing oneself in different social spheres and societies, has become a task which is increasingly experienced not only by migrants but by all members within more or less radically changing societies. Therefore post-modern thinking has proposed to leave the classical concepts of identity focusing on continuity and coherence behind. These concepts cannot grasp - so the argument the increasingly fluid and playful orientations and the decreasing localization of persons in specific social contexts. However, when looking at biographies it becomes empirically evident, that activity to connect to, but also to disconnect from collective entities, not least in reference to their historical dimensions, has not disappeared. The experience of discontinuity and incoherence between different social worlds is still experienced somehow as disturbing if it is not limited to a specific life period but becomes an involuntary experience in the long run of a life.

Since the term collective identity still has some implications of being something essentially given, continuous or hardly changeable, it might be helpful to look for alternative concepts addressing the issues at stake. At this point I found the concept of we-relations which has been developed by Alfred Schütz [37] helpful. His concept of anonymous we-relations is based in interactive processes from which also connections to distant persons and groups develop by distinguishing between We and Them. A We is created by a simultaneous flow of experiences and the concurrent fundamental reciprocity of perspectives. The assumption is that the orienting stock of knowledge (Schütz) is shared, and reciprocity of perspectives is possible also within a group or collective with members we never have met. This is the basis of collectivities which are formed by differentiating from each other in either specific ways [9, 38]. The Schütz' concept of we-relations and its further developments allow focusing at how belonging to a collective We is created by practices in the sphere of everyday life as well as within a life-time andmore-generational relations. It is possible to ask how biographers relate to we-entities, however imagined they might be, and what role different we-relations play in the construction of biographies. Concerning the construction of we-relations in the context of migration we can further ask, in what way a person relates to her migration experiences, if at all, while constructing her/his biographically relevant we-relations. Did experiences connected to migration have a structuring impact on her or his we-relations, or were other experiences much more relevant?

In this perspective also migration experiences appear as embedded in other processes of biographical structuring and it remains an empirically open question, if and in what way they have an impact on biographies and their relations to collective entities. The growing potential of possible or impossible identification with old, new, renewed, appreciated, depreciated or ignored collectivities in migration processes increase the potential patterns of biographical constructions of we-relations. However, with the variety of possibilities of constructing we-relations their relevance does not simply diminish or even disappear. It seems rather evident that constructions of we-relations become more ambivalent. This in turn stimulates processes of clarification [39] which retain the question of we-relations - and concurrent to them the question of belonging - in a relevant area of biographical construction.

Based on phenomenological concepts developed by Bernhard Waldenfels[40] and Ortfried Schäfter[41], we can assume specific relations between We and Them. These relations can be contradictory (We are what They are not); complementary (They add to what We are and vice versa); regarded as being both parts of a universal whole (We all descend from the same ground); or as a dialogical relation of accepting differences (We are strange or different to Them in the same way than They are strange or different to Us). The form of relation between different collectivities manifests also in the kind of social border which separates Us from Them. Experiences of migration are shaped by experiences of moving across borders which are structuring a societal field by divisions between 'natives' and 'strangers', 'established' and 'outsiders' [42], 'friends' and 'enemies' [39], 'citizens' and 'foreigners'. These divisions, including their historical backdrop, become relevant mainly in biographies where multiple relations to socially divided collectivities are part of the lived life. The biographical handling between different we-relations emerging in the course of a migration process however is systematically not yet fully grasped.

\section{The research Context: East-West European Migration during the Cold War}

East-West-migration during the Cold War was obviously structured by a contradictory and polarizing system border of the kind: We are the contrary of what They are. With the fall 
of the Iron Curtain this division with its relatively hermetic border started to dissolve. At the same time, its consequences regarding orientations in everyday life became more visible in the now increasing encounters between those raised in the East or West. Furthermore, new divisions and borders were created by the reorganization of the European Union. The new borders referred no longer to the distinction between 'socialism' and 'capitalism', but to national distinctions and in the end to the distinction of being European or Non-European in cultural categories.

The empirical research is based on narrative interviews which have been developed by Fritz Schütze[7], and biographical case-reconstruction put forward by Gabriele Rosenthal [15] who draws also from Structural Hermeneutics of Ulrich Oevermann and Thematical Field Analyses of Wolfram Fischer-Rosenthal. I conducted 20 interviews with men and women first with a wide scope including migrants who were raised in Hungary, Russia, Poland, Bulgaria and Romania, having different national or ethnic backgrounds, and who moved to East respectively West Germany in the period between 1960 and 1989 at different ages (17 to 53). In the later stage of the research, I focused on men and women coming from Romania with different cultural and national backgrounds (e.g. Romanian, Armenian, Hungarian, Jewish, Swabian), and who moved to the West in the mentioned period (for more details see [6]). In a second research field I analyzed migration biographies in the context of an EU-project on Social Strategies in Risk Societies (SOSTRIS) [43]. In this project, 42 migration biographies connected with different countries and continents were elicited in seven European countries and discussed in the meetings and publications of the project. This material has built a rich background for comparisons and generating wider reaching conceptual generalization.

In the interviews I conducted it was striking how intensively the issue of national identity was talked about. It was dealt with at length in nearly every interview, although neither the opening question nor the narrative questioning in the second part of the interview $[7,44]$ focused on this aspect. Even though nationality issues had a different meaning for the construction of the biography in the various cases, their thematization always was linked to the historic changes of 1989 , after which the self-location had to be recreated in relation to the dissolution of the border, which had formed the migration experience and for some to a certain extent also the whole biography. Thus, the thematization of national identities referred mainly to actual processes of socio-historical changes. It was not presented as a basis to construct biographically relevant and continuous we-relations, but as an actual challenge to which the interviewees felt provoked by the processes of re-positioning and re-evaluating of cultural connections and differences in the European context. The re-making of national identities was part of the actual re-structuring of whole Europe. The way in which the interviewees related to national identity was different, but the differences did not follow the respective national origin. A huge variety of how national identity was re-made could be observed between those coming from the same country. Some identified more or less intensively with the context of origin (I am Russian, Romanian etc.), others denied their formerly ascribed national identity and positioned themselves in the (western) context of arrival (I am German and not x,y). Some denied having a national identity at all (I don't belong anywhere). It was remarkable that many remained ambivalent in a dynamic of attraction and rejection when relating themselves to a national collectivity (yes, I am Romanian, but also not). I got interested especially in this ambivalence and started to analyze it in biographies connected with Romania, since here it appeared in high gear.

When compared with interviews conducted with migrants from Hungary, Poland and Russia who moved during the same period to East or West Germany, the interviews with migrants from Romania show clearly that, before 1989, the differences between experiences of crossing the border were not shaped primarily by the migrants' national background. Whether the migration ended in East or in West Germany, and whether it was shaped as a legal or illegal move was much more important than whether the migrants had an ethnic Romanian, German, Jewish or Armenian background coming from Russia, Romania, Poland, or Hungary. Only when after 1989 the discourses on East European countries changed [45], and especially the discourse on Romania became mainly pejorative [46], the descent from a national citizenship respectively an ethnic 'origin' became more relevant and even crucial placing migrants in a specific position. A different immigration status was ascribed to different groups of migrants on the basis of different symbolic and cultural assets. In other words, it now made a difference whether the migration had begun in Romania, Hungary, Poland or Russia, and whether the migrants presented themselves as having a Jewish, ethnic German, Armenian, or Roma background.

I will not go into more detail concerning the process of stigmatization Romania underwent in the discourse of public media specially in Germany and Austria after 1989 with the underlying question, whether this country can be regarded as part of Europe or has to be assigned to an 'uncivilized Balkan'[47]. I just want to mention that this discourse in these times had its effect on the self-positioning of migrants coming from Romania and especially on their ambivalent attitude in defining themselves as Romanian or rejecting this ascription. I will now turn to the case example in order to show a pathway of ambivalent identification with ethnic or national collectivities in its biographical context.

\section{We-relations in the Case of Stefan Georgescu}

Stefan Georgescu was born 1950 in Bucharest as son of an assimilated Armenian father and an Armenian mother. The language shared with his mother and father was Romanian. From his grandfather from the mother's side he learned 
Armenian, but refused at the age of eight to speak Armenian. Stefan Georgescu went through the socialist school system without difficulties and specialized already from the beginning in ballet dancing. When he was 12 years old his parents started to apply for an emigration visa, which failed time and again. Stefan was kept away from the tensions caused by this situation within the family. However, he had to learn to think 'double-tracked' - as he puts it - in order not to get involved in the conflict between the Armenian minority-milieu and the state-socialist system. By this double-track-thinking Stefan could participate in school life and develop his artistic career relatively untroubled but remained excluded from relevant decisions and information within the family. After completing the lyceum at the age of nineteen, Stefan was admitted to continue his education as ballet dancer in the most prestigious institution of Romania. Thus he had gained access to the cultural elite of the country. Just at that point, in 1969, the nuclear family got the visa which allowed them to immigrate first to the Lebanon and after six months to the United States.

In the US Stefan could continue his artistic career only under highly precarious financial circumstances. In the light of these experiences Romania appeared to him as the more 'civilized', socially balanced, and culturally superior country. In contrast, the United States showed as crude, focused on money and in the end appeared as 'uncivilized'.

"I came to America and my first reaction was, actually we come from, we descended from a more civilized country. (...) In America I have experienced the images of capitalism that we had learned in school: how bad capitalism is, the boss smoking a Havana, just like the cliché. My teacher smoked Havana and I smelled a Havana for the first time in my life. It smelled terrible, I didn't like it at all-these uncivilized habits, this coarseness, this rudeness (...) the whole mentality was strange. (...) America was Kafkaesque to me." (Stefan Georgescu I, 1994: 66)

Surprisingly, even the clichés Stefan learned in school about the world beyond the 'socialist' border gained some plausibility. At that time the border which organized Stefan's perception of different and contradictory worlds in the immigrant situation was clearly defined as one between 'capitalism' and the 'socialist' Romanian society, along which he explored many other dissimilarities. The Havana smoking, professionally as not very excellent experienced ballet teacher, for whom Stefan's parents had to sacrifice a high amount of payment, became a condensed symbolic expression for the culturally 'crude' US. Also the mixing of religion and money by the inscription on the Dollar 'in God we trust' caused a fundamental irritation concerning Stefan's moral landscape. Stefan reconstructs this irritation in the interview by explaining that in the orthodox religion money is connected with the evil, and not with God. At that time, for Stefan Romania and especially its cultural elites were evidently part of the European 'civilization' as a whole, even though Europe had divided in East and West after the Second
World War. Against this background and being in the US, Stefan located the border between not only different, but opposite worlds as one between America and Europe.

After Stefan had completed his artistic education he left for Germany with a grant in 1974, while his parents remained in the US. Moving all over Western Europe, he continued his professional career on the highest level possible. His life during this period was that of a cosmopolitan artist, oscillating between France and Germany over nearly ten years. Stefan identified with this world in which migration was no longer related to the Iron Curtain as a separating line between capitalism and socialism creating disturbing experiences of difference. However, in 1981 he manifestly got again in touch with the division of Europe when he fell in love with an Armenian woman living in the Soviet Union.

"When I got into a new phase in which I tried to learn Armenian, I wanted to marry an Armenian women in the Soviet Union. When I lived in Berlin, in 1981, I travelled to Moscow, as tourist so to say, it was shortly after Afghanistan [smirks], and I had a green card. My parents said "you are crazy", because, I mean (...); errr they kept me in, they stopped the plane, at my return, and I had to stand close to the others, to those guys [the security officers]. Well, and I wanted to practice Armenian with my mother, my parents live in the US, but she knew why, because I wanted to marry an Armenian woman. She was completely against that I went to the communists because of an Armenian woman. [Imitates the grim tone of his mother] "Couldn't you find another one?" Yes, but I had to see her. Okay, and I said "golly, but we are Armenian, I mean why ..." I always tried to speak Armenian [again as resolute mother] "Well, why you want to speak Armenian? What are you, a nationalist? We are from Romania; here [in the US] we do not need to speak Armenian." ' (Stefan Georgescu 1994: 28)

This incident took place in the period when Stefan lived an entirely cosmopolitan life, constantly moving between countries and continents. In this period he felt, however, a 'handicap' not being able to say 'what you are' when it came to national identities. Against this background also his love life seems to be involved in a process of relating to an ethnic identity, concretely to 'being Armenian'. The way Stefan quotes from the arguments with his mother about what it might be to be an Armenian indicates that at this point of his life for Stefan his Armenian identity became relevant in the context of a possible marriage and building a new family. The fact that he had dropped the Armenian language as a child shows that his self-definition as Armenian was nothing continuous but arose in a specific period of his life. Given the unpleasant, if not even dangerous situation at the Moscow airport, this marriage, however, did not happen.

A professional crisis beginning in 1990 forced Stefan to profoundly deal with his life path and future aspirations again. Living in Berlin at that time he could not continue his artist performances on the highest level possible which he 
already had achieved by performing in the most prestigious places of his field in Europe. Up to this point he had used his artistic education in Romania as a cultural capital which distinguished him from others and made him outstanding in the field. After the fall of the wall it became apparent, that Romania, also for Stefan himself, was no longer a point of reference constructing cultural capital, but turned out to be a 'destroyed country'. Concurrent with the historical upheaval Stefan's we-relations were challenged again. From his perspective at the time of his professional crisis, Romania appeared now as 'uncivilized', like a 'ruined vase', on which Stefan could not build the continuation of his career. Similarly to the typical experiences of the returning emigrant as described by Alfred Schütz [48], he had rediscovered Romania during extended travels in the early 1990s after having lived for twenty years in the West. This also formed his perspective on the country he "came from", which now appeared to him as devalued mainly in terms of material decline, but also in terms of political and intellectual crisis. Although he tried to dissociate himself from Romania as a biographically relevant context, his reflections in the initial quote of this article show that his birthplace still meant something to him. Nonetheless, Stefan in Germany defended Romania against the media's dominant negative representation of it, mainly by highly selective reporting that almost always creates an image of Romania as part of the 'barbaric Balkans'. At that point in his life, shaped by a professional crisis, Stefan was, even if ambivalently, strongly attached to Romania as a context with which he had identified positively in his youth, but which now appeared demoralized. In the overall evaluation of his life story he states:

"I was very attached to my place [in Bucharest] and suddenly I was forced to become a professional emigrant in my life-reluctantly; I have no talent for that [laughs] ... I wish I were no longer an emigrant" (Stefan Georgescu I, 1994: 70).

Seen from the bleak present perspective of his discontinued professional life in the West, the emigration retrospectively constitutes a turning point which separated Stefan from an easy life, including the prospect of a splendid career in Bucharest, the capital of Romania which represents Romania's modern urban life. But seen from the perspective of a struggling country with a severely diminished cultural life in comparison to the period during which Stefan lived there, his emigration seems to have saved him in the nick of time from many hardships. Seen from this perspective, his professional career has been a success, but seen from the actual professional situation in the West it seems to have failed. Torn between these two biographical perspectives, Stefan has difficulty detaching himself from Romania as the context which formed his successful past.

In this situation the Armenian family background became relevant as another possible point of reference for constructing we-relations. It bears the potential to dissolve the former polarization between America and Europe, Capitalism and Communism, since "Armenians live all over the World". But also this point of reference turned out to be problematic and rather intensified the question of belonging than helped to solve it. After 1989 Stefan began dealing for the first time in his life with his family background and its interconnection with Romanian and German history. He learned that his grandfather in the early 60 ies was denounced by an Armenian of having 'gold savings'. This led to a two years internment about which Stefan was not informed at that time. Moreover, he learned that the savings of his grandfather probably stemmed from his grocery shop and specifically from his business relations with German soldiers during the Second World War. Apart of the irritating handling of secrets within the family, a disturbing ambivalence is connected with the Armenian family history as well: being collectively related to the Armenian Genocide on the one hand side, and with the grandfather's business relations to the Nazi-war-machinery on the other side, which both questions Stefan's decision to locate in Germany. This point of view is fostered by public discussion of the Holocaust in Germany, which challenges Stefan to deal with his family and community history as one marked by persecution, but also by a potentially compromising closeness to the Nazi-Regime.

Seen in the context of his family history, with its connections to German and Romanian history, Stefan's own life with its manifold migration experiences now appeared much more fragile than it had in his professional situation, where migration had become a normal condition. The family history added a historical and existential dimension to the biographical uncertainty and discontinuity which had become severe during Stefan's professional crisis after 1989. The emigration from Romania now symbolizes an expulsion from certainty and the beginning of permanent exile. For Stefan in the actual situation the question became relevant, from which place and from which time perspective he can organize his embeddedness in professional, familial and collective we-entities. The question can no longer be answered in a way that permanent skepticism can be calmed. In the attempt to clarify we-relations even new questions, old conflicts and uncomfortable proximity arise. The preoccupation with different we-relations does not provide a stable new orientation and identification, but rather increases the feeling of dislocation. Stefan Georgescus solution was to reject either identification with national we-entities as to escape a situation in which ambivalence cannot be clarified but seems to increase the more one deal with questions of belonging [39]. The actual rejection of collective belonging in Stefan's case takes place in reflexive loops which remain centered - at least at the time of the interview - on the question of belonging.

In summary, for Stefan Georgescu his ethnic and national we-relations became relevant in different life contexts at different times gaining in each case a specific meaning. In order not to be different from the majority of children Stefan rejected to continue speaking Armenian as soon as he entered school at the age of six. However, being strongly attached to his Armenian grandfather he learned to think 
'double-tracked' especially during the long period of the families' attempts to emigrate from Romania in order to avoid conflicts between the families' belonging to the Armenian milieu with its small business structures and the state socialist society. In the US Stefan felt mainly European. Europe to him meant at that point to be part of a high culture as well as of a socially balanced society. In the light of this distinction the border between 'socialism' and 'communism' interestingly was felt as one between 'America' and 'Europe'. Living a cosmopolitan life in Europe the Armenian background as well as the dividing border between East and West within Europe became relevant again in a love affair with an Armenian woman from Moscow. During his professional career Stefan drew from a specific artistic background connected to and achieved in Romania as a source to develop a distinct profile as artist. The relations to all of his ethnic and national collectivities became finally a strongly questioned biographical topic in the context of a professional crisis beginning in the 1999ies. It was during this period, in which also the interview took place, when Stefan dealt in detail and at length with his family history in the context of Armenian, Romanian and German history. The preoccupation with these we-relations ended up in the paradox that they became more and more relevant the more Stefan tried to get rid of them. However, when looking at Stefan's further professional career up to today it is likely to assume that meanwhile his professional life has consolidated again, and that his we-relations are no longer a disturbingly relevant topic of his biography.

\section{Conclusion}

The biography of Stefan Georgescu with Romania as context of departure and ending up in Germany at the time of the interview was chosen because it shows a typical pattern of changing we-relations in this migration field developing mainly retrospectively after 1989 as an ambivalent and even paradoxical construction of collective belongings. In many interviews I conducted during my research, a specific dynamic of dealing with ascribed as well as accepted or chosen we-relations became apparent. While trying to get rid of a belonging to Romania as a devalued and even stigmatized country after 1989, this national belonging gained much more biographical relevance than it had had before. Paradoxically, experiences of cultural difference which had taken shape in the process of migration, in most cases far before 1989, and which meanwhile had dropped to the background even to the extent that most of my interviewees refused to see themselves as 'migrants', became relevant after 1989 in a situation when the most polarizing system border, the Iron Curtain, had fallen apart. 'Coming from Romania' now meant something different than in the period of the Cold War. People descending from Romania now were no longer addressed as refugees from a dictatorship, but as refugees driven by poverty, regardless of the concrete circumstances of their migration and integration in the German society. This new position in the society of residence contested we-relations connected with Romania. It required more attention than the biographers would have preferred, and left them with the ambivalent situation of defending to be Romanian at least to some extend and rejecting it at the same time.

After 1989 Romania was considered as being on the 'other side' of Western Europe [49]. The cultural polarization between Romania and the West was pronounced in political and media discourses especially during the period of decision making where the new geopolitical border lines of Europe should be drawn. In this period the changing perceptions of collectivities within Europe were highly virulent and provoked biographical reflection of one's own position(s). In a situation where biographically relevant collective entities are societally constructed as opposed the ambivalences and paradoxes of maintaining and re-creating one's belongings become more evident than in periods of societal stability where they can drop to the background of implicit and taken for granted orientations. In such situations, different we-relations and potential contradictions between we-relations become aware and have to be reorganized.

In general, one can assume, in migration processes specific conditions emerge in which we-relations have to be re-created, changed or continued by acting subjects. The horizon in which a biography can be connected to different collectivities widens significantly. In these processes different perspectives, values and experiences connected to different collectivities have to be related in the field of interaction and personal orientation as well as in specific societal contexts. The configuration of the relations to different collectivities enters the field of everyday life interaction and biographical orientation, especially if it is organized as contradictory polarization, as e.g. between East and West.

In case one is involved in sharing different and societally even polarized collective relations the question comes up, from which perspective the own experiences and orientations should be understood and organized. If one perspective is not rejected in favor of another, an ambivalent situation arises in which things, events, experiences; values can not only be seen from different, but from contrary viewpoints. In the interviews I conducted the contradictions relate mainly to values and attitudes [30] concerning different meanings of religion, money and morality; family, marriage and love; of success and failure in the professional career; and last not least of the discursively attributed meaning of national belonging as being Romanian, Armenian, German, Jewish, Ukrainian and others.

Not surprisingly, the ambivalence becomes an issue mainly during situations of crossing borders in which individuals from 'different sides' are interacting with each other. Against this background it becomes clear that paradoxes and ambivalences in we-relations are structurally 
based in the relations the respective societies, milieus, groups have developed historically as well as presently. At the same time, the paradoxes and ambivalences are ascribed to the individuals who have to deal with them in their biographical contexts. They seem to develop 'traditional' identities being highly attached to collectivities in contrast to 'modern' ones which are assumed to be organized more individually. This view on migration biographies overlooks that in migration processes ascribed as well as experienced collective identities create ambivalences and even paradoxes which in turn cause the need to deal with contradictory positions and validations concerning essential questions of orientation and acting. These contradictions have to be integrated into timely (relatively) stable and (relatively) coherent constructions of orientation and action as not to allow them to become a permanent issue of biographical work on questionable and doubtful knowledge orienting us in everyday life [37, 48]. However - and this is the general paradox - in processes of dealing biographically with different relevant we-relations as orienting systems of knowledge, the fragility of we-constructions becomes more and more obvious. In such a situation every attempt to construct continuity and coherence in relating to collectivities which are reaching beyond one's own life time and acting sphere leads to experiences of discontinuity and difference. And these experiences in turn fuel further attempts to create at least some continuity and consistence in one's we-relations. The creation of belonging to ethnic and or national collectivities in migration processes thus can be much more an answer to actual challenges of reorganizing one's life than an essential part of an identity assumed as primordial. In this perspective a fundamental process of modernity like Zygmunt Bauman has described it seems to be also part of biographical activities especially in migratory situations. Any attempt to deal with ambivalence by creating 'clear' collective identities providing continuity in a stable order ends up in increasing ambivalence since the boundaries become more and more fluid the more we are looking at and dealing with them. The 'clearing' activities which are undertaken by migrants who are crossing societal boundaries in many ways show that they still are specifically con-fronted with the task of dealing with dominant patterns of creating belonging e.g. by principles of ascriptive placing while constructing ethnic communities as well as nation states. At the same time, they have to overcome these principles in order to escape the paradoxes created by them.

The stories and histories of concrete biographical actors show that collective belonging no longer structures biographies as something given and taken for granted. But it also becomes clear, that social positioning as immigrant, emigrant stranger or foreigner along (culturally, ethnically and/or nationally) ascribed belongings still plays an important role in migration processes. These ascriptions have to be answered by biographical work[26] oriented at organizing one's own life along self-defined constructions of belongings, which throughout have become reflexive and still have the function to (symbolically) embed one's own life in continuities and social collectivities reaching beyond our own lifetime or nuclear social groups [29, 30]. Collective histories with their specific family and milieu histories are still an 'imagined place' of building we-relations and social communities. [5] The impossibility of doubtless and unambiguous we-relations in families, milieus and societies touches the (existential) question what happens to our life if we are no longer able to embed it in local, societal, global, historical, and in the end symbolic worlds in whatever ways, without being confronted with fundamental doubts, ambivalences and paradoxes. In the end it touches the question of our sociality and historicity if not even that of our sociability which is connected to social communities [51]. In this perspective questions of collective belonging and the respective ambivalences, especially in migration processes across polarized and polarizing borders, are also part of an existential dimension which might explain why they are such a heated and challenging topic. Maybe those migration biographies in which ethnic and national we-relations increasingly create ambivalences and even paradoxes are symptomatic for a societal situation in which ascribed belonging still is decisive for placing people in social spheres hierarchically, whereas the formation of collective identities based in ethnicity and nationality is highly questioned and even appear as suspect from 'modern' viewpoints.

\section{Acknowledgements}

I would like to thank all interview partners who were ready to tell their life-stories with their partly difficult migration experiences, and even though many of them were not happy to be addressed as 'migrants'.

\section{REFERENCES}

[1] M. Castells. The Information Age: Economy, Society, and Culture, Volume 2: The Power of Identity. Oxford and Malden, MA: Blackwell Publishers, 1997.

[2] N. Glick-Schiller, 'Blood and Belonging: Long-Distance Nationalism and the World Beyond', in Susan Mc Kinnon and Sydel Silverman (eds) Complexities. Beyond Nature and Nurture, Chicago: University of Chicago Press, pp. 289-312, 2005.

[3] K. Schittenhelm (ed.) Concepts and methods in migration research. Conference Reader. Available at: www.cultural-capital.net, 2007.

[4] R. Wodak, de Cillia, Rudolf and Reisigl, Martin, The Discursive Construction of National Identity, Edinburgh University Press, 2009.

[5] B. Anderson, Imagined communities. Reflections on the origin and spread of nationalism, London: Verso 1999. 
[6] R. Breckner. Migrationserfahrung - Fremdheit - Biografie. Zum Umgang mit polarisierten Welten in Ost-West-Europa, Wiesbaden: Verlag für Sozialwissenschaften, 2009.

[7] F. Schütze. 'Biography Analysis on the Empirical Basis of Autobiographical Narratives: How to Analyse Autobiographical Narrative Interviews, Part I+II', in European Studies on Inequalities and Social Cohesion, Vol. I+II, pp 153-242; 5-77, 2008.

[8] R. Jenkins. Social Identity, London and New York: Routledge [third edition] 2008a.

[9] R. Jenkins. Rethinking Ethnicity. Arguments and Explorations, London: Sage, 2008b.

[10] P. Weinreich. 'Variations in Ethnic Identity: Identity Structure Analysis', in K. Liebkind (ed.) New Identities in Europe. Immigrant Ancestry and the Ethnic Identity of Youth, Aldershot/Vermont: Gower, 41-76, 1989.

[11] G. Riemann and F. Schütze 'Trajectory as a basic theoretical concept for analyzing suffering and disorderly social processes', in D. Maines (ed.) Social Organization and Social Processes, Hawthorne, NY: Aldine, pp. 333-57, 1990.

[12] U. Apitzsch and E. Inowlocki. 'Biographical Analysis: a 'German' school?', in Prue Chamberlayne, Joanna Bornat and Tom Wengraf (eds) The Turn to Biographical Methods in Social Science, London and New York: Sage, pp. 53-70. 2000.

[13] M. Kohli. 'The Battleground of European Identity', European Societies vol. 2, no. 2, pp. 113-37, 2000.

[14] W. Fischer-Rosenthal, 'Address lost: How to Fix Lives. Bio-graphical Structuring in the European Modern Age', in Roswitha Breckner, Devorah Kalekin-Fishman and Ingrid Miethe (eds) Biographies and the Division of Europe, Opladen: Leske + Budrich, pp. 55-75, 2000.

[15] G. Rosenthal. 'Biographical Research', in C. Seale, G. Gobo, J.F. Gubrium and D. Silverman (eds.) Qualitative Research Practice. London: Sage, pp. 48-64, 2004.

[16] A. Strauss. Mirrors and masks. The search for identity, Glencoe: Free Press of Glencoe, 1959.

[17] W. Fischer- Rosenthal. 'The problem with identity: Biography as Solution to Some (Post)-Modernist Dilemmas', Comenius, vol. 15, pp. 250-65, 1995.

[18] D. Bertaux (ed.). Biography and Society. The life history approach in the social sciences, Beverly Hills: Sage, 1981.

[19] F. Schütze. 'Pressure and Guilt: War Experiences of a Young German Soldier and their Biographical Implications. Part 1 and 2'. International Sociology, vol. 7, no. 2, pp. 187-208 and no. 3, pp. 347-67, 1992.

[20] W. Fischer-Rosenthal and P. Alheit(eds). Biographien in Deutschland. Soziologische Rekonstruktionen gelebter Gesellschaftsgeschichte, Opladen: Westdeutscher Verlag, 1995.

[21] J. Bornat, P. Chamberlayne and T. Wengraf (eds). The turn to biographical methods in social science. Comparative issues and examples, London: Routledge, 2000.

[22] R. Breckner, D. Kalekin-Fishman and I. Miethe, (eds) Biographies and the Division of Europe. Experience, Action and Change on the 'Eastern Side'. Opladen: Leske + Budrich, 2000 .

[23] R. Humphrey, R, Miller, and E. Zdravomyslova. Biographical Research in Eastern Europe, Aldershot/Burlington: Ashgate, 2003.

[24] R. Miller. Biographical Research Methods, 4 Volumes, London et.al.: Sage, 2005.

[25] G. Rosenthal (ed.) 2010 The Holocaust in Three Generations: Families of Victims and Perpetrators of the Nazi Regime, Opladen and Farmington Hills: Barbara Budrich, 2010.

[26] L. Inowlocki and H. Lutz. 'Hard Labor. The "Biographical Work" of a Turkish Migrant Woman in Germany', European Journal for Women's Studies, vol. 7, no. 3, pp. 301-19, 2000.

[27] G. Riemann. (ed.) Doing biographical research. FQS - Forum Qualitative Social Research vol. 4, no. 3: www.qualitative-research.net/fqs/fqs.htm, 2003.

[28] H. Lutz. Migration and Domestic Work. A European Perspective on a Global Theme. Aldershot: Ashgate, 2008.

[29] R. Breckner, Case-Oriented Comparative Approaches. The Biographical Perspective as Opportunity and Challenge in Migration Research, in: Karin Schittenhelm (ed.) Concepts and Methods in Migration Research. Study Group „Cultural Capital during Migration“ - Conference Reader, pp. 113 - 152, 2007.

[30] W. I. Thomas and F. Znaniecki. The Polish Peasant in Europe and America. Monograph of an Immigrant Group, 5 Volumes, Boston: Richard G. Badger, 1918-1920/1923.

[31] M. Kohli, 'Biographical research in the German language area', in Z. Dulcewski (ed.) A commemorative book in Honor of Florian Znaniecki on the Centenary of his Birth, Poznan, pp. 91-110, 1986.

[32] J. Bruner. 'Life as Narrative', Social Research, vol. 54, no. 1, pp. 11-32, 1987.

[33] C. Kohler Riessman. Narrative Analysis, Newbury Park: Sage, 1993.

[34] G. Rosenthal. 'Reconstruction of Life Stories. Principles of Selection in Generating Stories for Narrative Biographical Interviews', Narrative Study of Lives vol. 1, pp. 59-91, 1993.

[35] L Inowlocki. 'Doing "being Jewish": Constitution of "Normality" in Families of Displaced Persons in Germany', in Roswitha Breckner, Devorah Kalekin-Fishman and Ingrid Miethe (eds) Biographies and the Division of Europe, Opladen: Leske + Budrich, pp. 159-78, 2000.

[36] F. Barth. Ethnic groups and boundaries. The social organization of culture difference. Oslo: Universitetsforlaget, 1982.

[37] A. Schütz and T. Luckmann. The Structures of the Life World, Evanston: Northwestern University Press, 1973.

[38] R. Breckner and W. Weber. Austrian and/or/nor German? The Meaning of 'Nationality' in Biographical Interviews with Austrian World War II Veterans, in: Michael Gehler und Ingrid Böhler (Hg.) Verschiedene Europäische Wege im Vergleich. Österreich und die Bundesrepublik Deutschland 1945/49 bis zur Gegenwart, Innsbruck/Wien/Bozen: StudienVerlag, 372-387, 2007. 
[39] Z. Bauman. Modernity and ambivalence, Cambridge: Polity Press, 1991.

[40] B. Waldenfels. Topographie des Fremden. Studien zur Phänomenologie des Fremden, vol. 1, Frankfurt am Main: suhrkamp, 1997.

[41] O. Schäffter. 'Modi des Fremderlebens. Deutungsmuster im Umgang mit Fremdheit', in Ortfried Schäffter (ed.) Das Fremde. Erfahrungsmöglichkeiten zwischen Faszination und Bedrohung, Opladen: Westdeutscher Verlag, pp. 11-44, 1991.

[42] N. Elias, J. L. Scotson. The established and the outsiders. A sociological enquiry into community problems, London: Cass, 1965.

[43] R. Breckner. 'Migrants': a target category for social policy? Experiences of first generation migration, in P. Chamberlayne, M. Rustin, T. Wengraf (eds) Experiences of social exclusion: biography and social policy in Europe, London, Policy Press, $211-226,2002$

[44] T. Wengraf. Qualitative Research Interviewing. Biographic Narrative and Semi-Structured Methods, London: Sage, 2001.

[45] M. Czyżewski. (ed.) Nationale Selbst- und Fremdbilder im
Gespräch. Kommunikative Prozesse nach der Wiedervereinigung Deutschlands und dem Systemwandel in Ostmitteleuropa, Opladen: Westdeutscher Verlag, 1995.

[46] R. Wodak and B. Matouschek ,'Wir und die anderen: Diskurse über Fremde', Journal für Sozialforschung, vol 33, no. 3, pp.293-302, 1993.

[47] M. Todorova. Imagining the Balkans, New York, NY: Oxford Univ. Press, 1997.

[48] A. Schütz. 'The stranger' and 'The homecomer', in Collected Papers, vol. 2, The Hague:Nijhoff, pp. 91-105 and 106-12, 1964.

[49] E. Stölting. 'The East of Europe: A Historical Construction', in Roswitha Breckner, Devorah Kalekin-Fishman and Ingrid Miethe (eds) Biographies and the Division of Europe. Opladen: Leske und Budrich, pp. 23-38, 2000.

[50] T. Luckmann, 'Zeit und Identität: Innere, Soziale und Historische Zeit', in Friedrich Fürstenberg and Ingo Mörth (eds) Zeit als Strukturelement von Lebenswelt und Gesellschaft, Linz: Trauner, 1986.

[51] C. Hoffmann-Riem. Elementare Phänomene der Lebenssituation, Weinheim: Deutscher Studienverlag, 1994. 